\title{
THE FACTORS THAT AFFECT THE FREE FLOW SPEED ON AN ARTERIAL IN ILORIN, NIGERIA
}

\author{
I. T. Yusuf ${ }^{\prime}{ }^{*}$, 0. O. Adeleke ${ }^{2}$ A. W. Salami ${ }^{3}$ and A. M. Ayanshola ${ }^{4}$ \\ 1,2DEPARTMENT OF CiVIL ENGinEERING, UNiVERSiTy OF ILORIN, P.M.B. 1515, ILORIN, KWARA STATE NIGERIA \\ 3,4DEPT. OF WATER RESOURCES AND ENVIRONMENTAL ENGINEERING, UNIVERSITY OF ILORIN, KWARA STATE NIGERIA \\ E-mail addresses: ${ }^{1}$ ityusuf4@gmail.com, ${ }^{2}$ adeleke.oo@unilorin.edu.ng, ${ }^{3}$ awsalami2009@gmail.com, \\ 4 engramayanshola@gmail.com
}

\begin{abstract}
Generic factors (weather, environment, vehicles, fixed roadway characteristics, pedestrian and traffic streams) singly or jointly influence the free flow speed. This paper, therefore, presents the outcome of the quantitative evaluation of the influence of these factors on the free flow speed on an arterial in a medium-sized urban settlement in Nigeria. Instantaneous speeds of forty test vehicles were observed at lull periods on the 7.1km-Offa GarageEmir's Road, Ilorin, with simultaneous collection of data on drivers' and vehicle ages, passenger occupancy, roadside parked vehicles and businesses. The geometric properties of the arterial were earlier established and segmented to four uniform sections. Result of computations using the category and statistical analysis show that the environment, pedestrian and roadway geometry have negative influences on the free flow speed. This can be confirmed by the poor relationship between free flow speed and these factors, with $R^{2}$ values of $14.9-55 \%$, and lower average free flow speed of commercial saloon cars on wet pavement than on dry pavement, with $12 \%$ percentage reduction. Adoption of design and analysis of traffic stream in Ilorin and other urban settlements in Nigeria is, therefore, recommended.
\end{abstract}

Keywords: Free flow, instantaneous speed, roadway geometry, in-vehicle data, traffic stream.

\section{INTRODUCTION}

Free flow speed can be defined as the drivers' desired average space mean speed in a low volume traffic stream when the density and flow theoretically tend to zero as mathematically represented by the fundamental traffic equation [1] and [2]. It occurs when no obstructions to flow either in terms of operational delays (congestion) or other adverse conditions prevail. Three principal factors such as (a) roadway geometry and condition (b) drivers attributes and (c) environment have been reported to influence the values in the American urban traffic streams and highways [3] and[4]. These authors showed from different studies that the percentage reduction due to the environment in the free flow speed are 8,14, 15 and $17-18$ respectively for wet pavement, high wind (greater than $24 \mathrm{~km} / \mathrm{hr}$ ), low visibility(less than $0.28 \mathrm{~km}$ ) and rains; with a combined effect of all in the range of $30-38 \%$. Additionally, [4] observed that drivers also adjust speeds by as much as $10 \mathrm{~km} / \mathrm{hr}$ less during heavy rains when visibility becomes substantially obstructed, while [5] equally identified drivers' attributes and vehicle characteristics as the major factors in the free flow speed in the urban traffic. Younger drivers (in age),level of passenger occupancy, age of vehicles and trip purpose have impacted higher values on the speed, while horizontal/vertical alignments and parked vehicles along the road impacted negatively on free flow speeds [6].

The free flow speed is very important in traffic stream analysis for incidents and bottlenecks and hence the factors influencing its value should attract equal, if not higher attention because it is the source and not the effect. Besides it shall be helpful in sensitivity analysis. No wonder the Highway Capacity Manual [7] underscores the importance of the various factors as pertaining to lane width/lateral clearance, the number of lanes and the driver's lateral wander etc.[8] used free speed modeling for urban arterials in Delhi, India 
by considering the traffic characteristics $\{[9]$ and [10]\} and road geometrics [11]. Indeed, [12] presented a chapter of detailed analysis of the effect of human factors (drivers') on the free flow speeds in the premise of person-machine control system. The phenomenon of perception-reaction time, control movement time responses to movement of other vehicles, handling of hazards in the roadway and the peculiarities of the different segments of driving population were examined, while the evolving formulation were tested with the American traffic situations and various models. Two of such models are the (a) Hick-Heyman's law [13] for perceptionresponse time and (b) Fit's law [14] of braking inputs. Of particular interest for Nigerian situation are the age of drivers, age and condition of vehicles, the roadway geometry and pavement condition. It is an open secret that majority of vehicles on Nigerian roads are old and second hand that have already operated on the streets of country of manufacture before being imported to this country. Obviously, the enumerated models can not completely address the Nigerian situation because Nigerian drivers must have, at least characteristic vehicle handling practices, which must reflect on the traffic stream operation.

Traffic stream analysis and design in Nigeria presently apply either the American or British values which are empirical evidences of the operation in the developed countries. Hence the assessment of the influence of some of these factors to reflect the traffic operation in Nigeria shall be a worthwhile exercise, in that the closeness of the prevailing values to those usually borrowed from other countries' traffic situation, environment and humane (driver) attributes, shall offer the desired confidence and reliability when used for Nigeria traffics. It will appropriately reflect on Nigeria's peculiarities, her drivers' characteristic behaviors behind the wheels, the vehicle conditions/age, passengers' perceptions of trip purpose and other latent issues or combined effects.

The aim of this study is, therefore, to establish both quantitative and qualitative measures of the influence of the roadway factors (geometry), pavement condition, human (drivers) and the environment; on the free flow speeds on a typical Nigeria urban arterial.

\section{MATERIALS AND METHODS}

\subsection{Studied Arterial}

The study arterial is located in Ilorin, the capital city of Kwara State, Nigeria. Ilorin city occupies and area of

about $89 \mathrm{~km}^{2}$ and located between latitude $8^{0} 25^{\prime} \mathrm{E}$ and $8^{0} 32^{\prime} \mathrm{E}$, and longitudes $4^{0} 30^{\prime} \mathrm{N}$ and $4^{0} 41^{\prime} \mathrm{N}$. The population of the city was estimated to be $777,667[15]$. The studied arterial is $7.1 \mathrm{~km}$ in length with the last $5 \mathrm{~km}$ dualised. It originates from the Offa Garage and terminates at the Emir's palace, Ilorin, the Kwara State capital in the central western part of Nigeria. The road traverses four distinct sections; in terms of different levels of the road way characteristic, land use (road side development and business) and traffic volume. The respective partitions are designated as sections A, B, C and D.

Section A: Offa garage to Gaa Akanbi Junction, which is the section without median, Section B: Gaa Akanbi Junction to "A" Division which is a section with isolated and dedicated educational or public buildings which is not densely populated and thereby having a low level of activities, Section C: "A" Division to Post Office, which is a central business district of the town and Section D: Post Office to Oja-Oba, the predominantly market and indigenous area of the town which is densely populated and thereby highly characterized by a high level of activities. Figure 1 presents the diagrammatic sketch of the studied arterial.

\subsection{Study Methods and Test Data \\ 2.2.1 Road and Traffic Characteristics}

The influence of the three factors of roadway characteristics, drivers (human) and environment were studied using the manual observatory approach for the road inventory, traffic volume and drivers characteristics at different weather conditions. The lull period was established in order to determine the timings for the speed measurement. Table 1 presents the geometric properties of the studied arterial while Table 2 presents the probable measurement timings of free flow speed for the various days of the week.

Table 1: Geometric characteristics of the studied Arterial

\begin{tabular}{lcccc}
\hline Section & A & B & C & D \\
\hline Length (km) & 2.3 & 1.5 & 0.9 & 2.4 \\
Overall width (m) & 20.8 & 29.2 & 28.6 & 19.5 \\
Roadway (m) & 8.10 & 10.7 & 10.7 & 7.10 \\
Shoulder (m) & 2.3 & 3.0 & 2.70 & 2.20 \\
Median (m) & 1.8 & 1.8 & 1.8 & 1.5 \\
Number of lanes of & 2 & $3 / 2$ & $3 / 2$ & $2 / 2$ \\
$\begin{array}{l}\text { Number } \\
\text { intersections of }\end{array}$ & 11 & 9 & 5 & 15 \\
$\begin{array}{l}\text { Number of traffic } \\
\text { controls }\end{array}$ & 1 & - & 1 & 1 \\
\hline
\end{tabular}




\subsubsection{Free Flow Speed Data and Factors}

The free flow speed measurement data was carried out simultaneously with drivers' attributes data collection using the in-vehicle method at predetermined lull periods with two observers. Forty test vehicles were selected ensuring that the two predominant passenger commuting vehicles (taxis) and small buses ("turo-turo") on the township roads were sampled. Observer (1) noted the instantaneous speeds (the speedometer reading) at three spots, approximately third portion along the length of each section of the arterial, while simultaneously observer (2) recorded the numbers of parked vehicles along the roadsides and passenger occupancy of the test car. Thereafter, both observers interviewed the drivers to obtain the relevant information about respective attributes of age, sex, vehicle age and condition and pavement condition. A category analysis of the mean speed with the various parameters or factors was carried out. A summary of the free flow speed with respect to various factors for section $A$ is presented in Table A1 of the Appendix. The mean free flow speed was calculated respectively for dry and wet pavement conditions for the four different sections.

Table 3 presents the matrix of the relationship between the average free flow speed and the driver's age for the four sections and subjected to statistical analysis. The average free flow speeds for the other three sections under consideration are summarized in Table 4 . The plot of the average values are shown in Figure 2 with slope computed as $-0.46 \mathrm{~km} / \mathrm{hr} / \mathrm{yr}$.

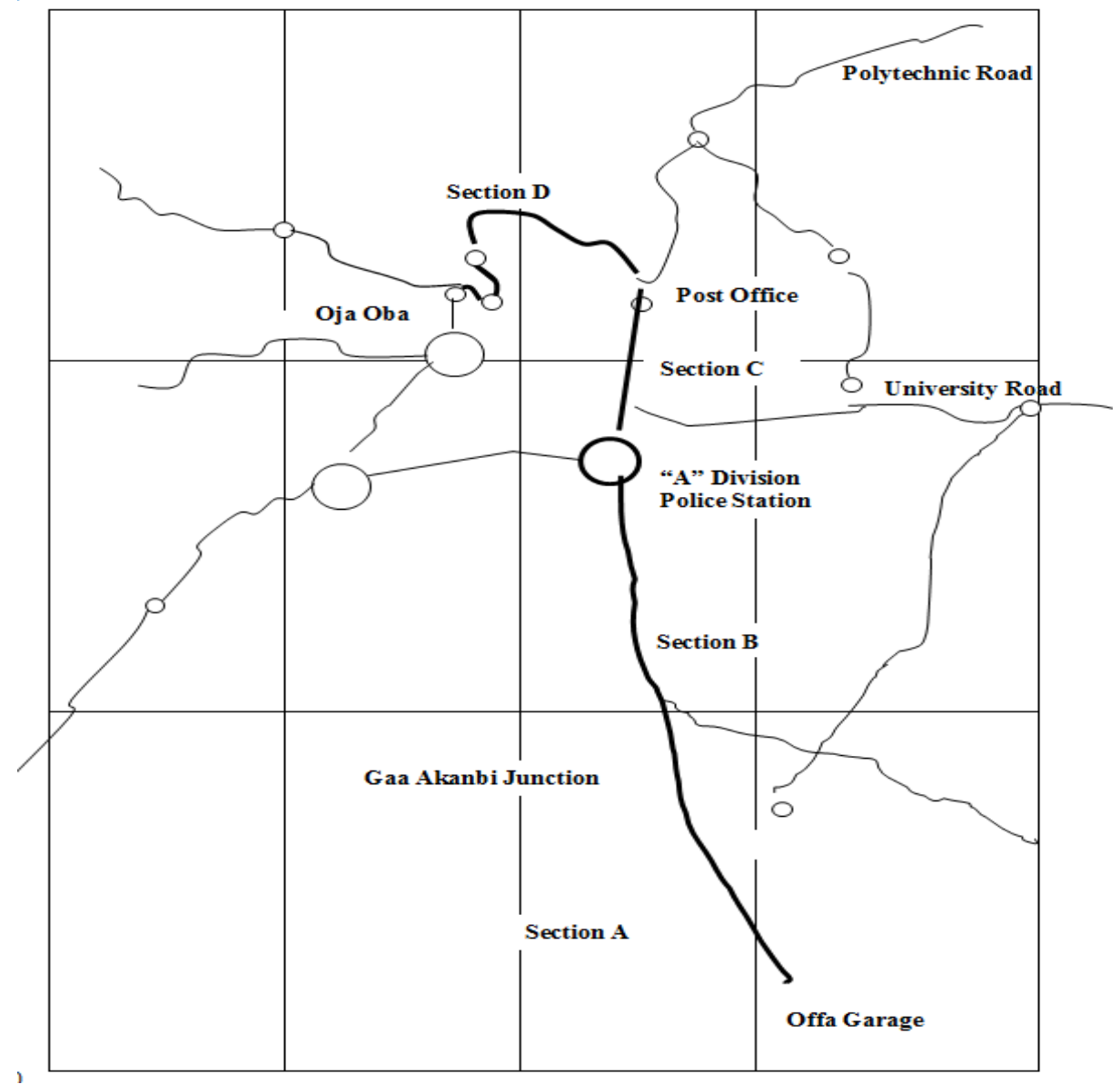

Figure 1: Geographical Presentation of Study Area

Table 2: Traffic Lull Periods on the Arterial

\begin{tabular}{|l|c|c|c|c|c|c|c|c|}
\hline \multicolumn{1}{|c|}{ Day } & \multicolumn{2}{c|}{ Section A } & \multicolumn{2}{c|}{ Section B } & \multicolumn{2}{c|}{ Section C } & \multicolumn{2}{c|}{ Section D } \\
\hline & Morning & Afternoon & Morning & Afternoon & Morning & Afternoon & Morning & Afternoon \\
\hline Monday & $7-8$ & $5-6$ & $7-8$ & $5-6$ & $7-8$ & $5-6$ & $10-11$ & $5-6$ \\
Tuesday & $7-8$ & $5-6$ & $7-8$ & $5-6$ & $7-8$ & $5-6$ & $7-8$ & $5-6$ \\
Thursday & $11-12$ & $1-2$ & $7-8$ & $1-2$ & $7-8$ & $3-4$ & $7-8$ & $5-6$ \\
Friday & $7-8$ & $5-6$ & $7-8$ & $12-1$ & $7-8$ & $3-4$ & $10-11$ & $5-6$ \\
Saturday & $7-8$ & $5-6$ & $7-8$ & $12-1$ & $7-8$ & $3-4$ & $7-8$ & $5-6$ \\
\hline
\end{tabular}


Table 3: Matrix of Free Flow Speed against Driver's Age

\begin{tabular}{|c|c|c|c|c|}
\hline $\begin{array}{l}\text { Driver's } \\
\text { Age }\end{array}$ & Section A & Section B & Section C & Section D \\
\hline $20-29$ & $\begin{array}{c}1,8,10,11,1921,30 \\
33,35,44,46,48\end{array}$ & $\begin{array}{c}1,2,7,8,20,32,33 \\
36,42,43,44\end{array}$ & $\begin{array}{c}7,8,11,14,19,22,25 \\
26,27,34,40,42,48,49\end{array}$ & $9,17,21,27,32,38,39,41,49$ \\
\hline $30-39$ & $\begin{array}{c}2,3,5,7,9,12,18 \\
20,24,31,32,34,36 \\
37,41,42,45,37\end{array}$ & $\begin{array}{c}3,4,5,6,9,10,11 \\
16,17,19,23,24 \\
25,29,31,37,38 \\
45,48,49,50\end{array}$ & $\begin{array}{c}1,2,3,9,15,17,18,23 \\
32,35,36,41 \\
43,44,50\end{array}$ & $\begin{array}{c}4,8,11,12,13,14,16,19,20 \\
22,26,33,40 \\
44,48\end{array}$ \\
\hline $40-49$ & $\begin{array}{c}4,6,13,14,16,17,22 \\
23,27,28,38,40 \\
49,50\end{array}$ & $\begin{array}{c}12,14,18,21,22 \\
26,27,28,30,39 \\
40,41,46,47\end{array}$ & $\begin{array}{c}6,10,12,13,16,21,24 \\
28,29,31,37 \\
45,47\end{array}$ & $\begin{array}{c}1,5,6,7,10,18,23,25,29,30 \\
31,34,36,42,43,45,46,47,50\end{array}$ \\
\hline $50-59$ & $15,25,39$ & $13,15,35$ & $\begin{array}{c}4,5,20,33,38,39 \\
46\end{array}$ & $2,15,24,28,36,37$ \\
\hline $60-69$ & $26,29,43$ & 34 & 30 & 3 \\
\hline
\end{tabular}

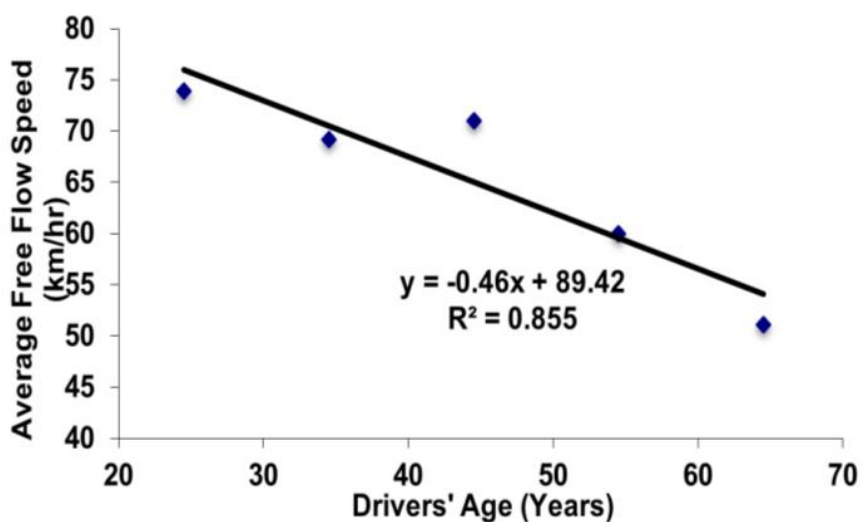

Figure 2: Relationship between average free flow speed and drivers' age

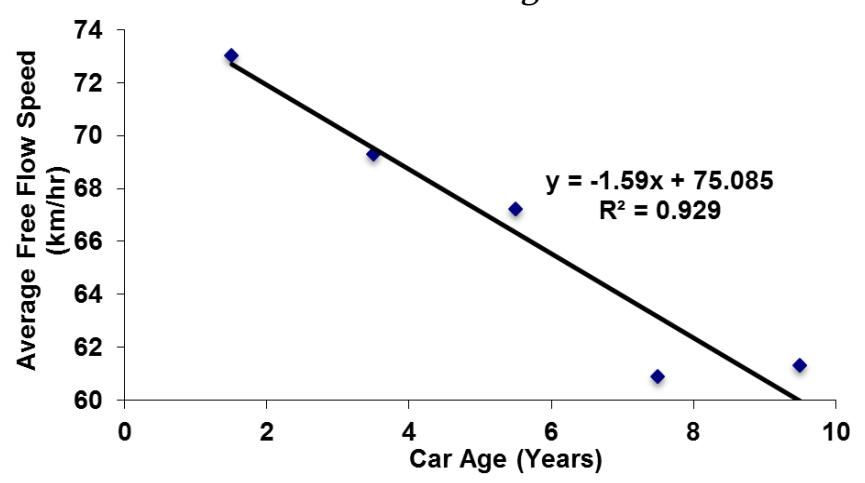

Figure 4: Relationship between average free flow speed and car age

The results of other factors (number of passengers in the car, car age and number of parked cars along roadsides) are displayed in Figures 3, 4 and 5.

\section{RESULTS}

\subsection{Free Flow Factors Relationship}

From the graph of average flow speed against number of passengers in car as shown in Figure 3, the slope value in $\mathrm{km} / \mathrm{hr} /$ passenger is -0.548 . From the graph of average free flow speed against car age shown in Figure 4 , the slope in $\mathrm{km} / \mathrm{hr} / \mathrm{yr}$ of age of car is -1.59 . The graph of average free flow speed against number

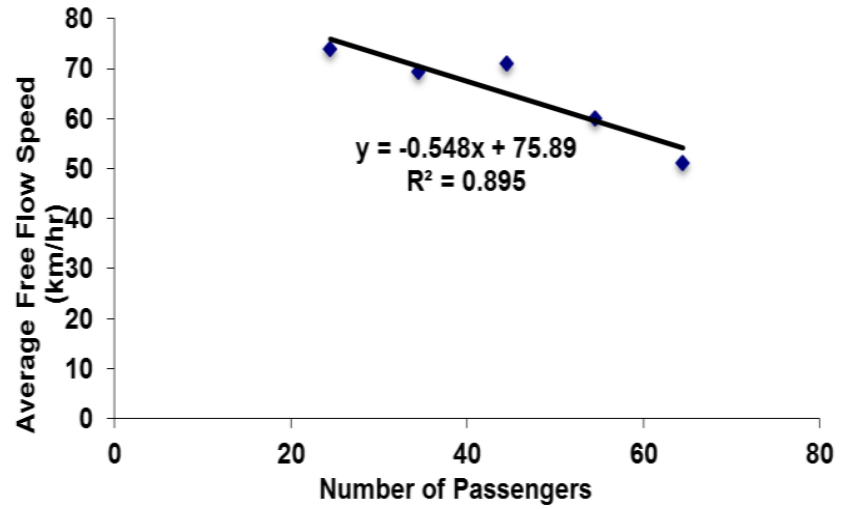

Figure 3: Relationship between average free flow speed and number of passengers in the car

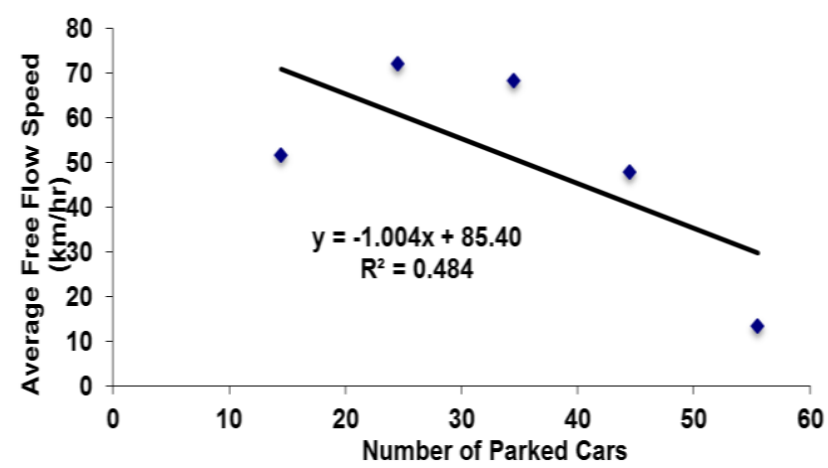

Figure 5: Relationship between average free flow speed and number of parked cars

of parked cars is shown in Figure 5. The relationship is of quadratic form with peak at about 25 parked cars.

\subsection{Free Flow Speed - Environmental Factor Relationship}

Table 5 presents the summary of statistic data (mean and standard deviation) for section A while Table 6 is the corresponding summary of true speed at $95 \%$ upper confidence level (mean +1.96 x standard error). There was a reduction of $0.5 \mathrm{~km} / \mathrm{hr}$ to $14.0 \mathrm{~km} / \mathrm{hr}$ speed on the road due to the wet condition which approximates to percentage reduction of $0.9 \%$ 
to $21.0 \%$. The corresponding values based on time means at $95 \%$ confidence levels were $1.7 \mathrm{~km} / \mathrm{hr}$ to $9.98 \mathrm{~km} / \mathrm{hr}$.

Table 4: Average Free Flow Speed - Driver's Age

\begin{tabular}{|c|c|c|c|c|}
\hline $\begin{array}{c}\text { Driver's } \\
\text { Age } \\
\text { (year) }\end{array}$ & $\begin{array}{c}\text { Section A } \\
\mathrm{km} / \mathrm{hr}\end{array}$ & $\begin{array}{c}\text { Section B } \\
\mathrm{km} / \mathrm{hr}\end{array}$ & $\begin{array}{c}\text { Section C } \\
\mathrm{km} / \mathrm{hr}\end{array}$ & $\begin{array}{c}\text { Section D } \\
\mathrm{km} / \mathrm{hr}\end{array}$ \\
\hline $20-29$ & 77.9 & 78.9 & 74.3 & 64.4 \\
$30-39$ & 73.1 & 75.9 & 67.9 & 59.8 \\
$40-49$ & 73.3 & 77.9 & 77.0 & 55.9 \\
$50-59$ & 52.8 & 66.1 & 68.6 & 52.5 \\
$60-69$ & 62.8 & 46.7 & 46.7 & 48.3 \\
\hline
\end{tabular}

\subsection{Free Flow Speed and Road Geometry/Condition}

Table 7 shows the summary of average free flow speed and geometric condition at each section of the road. The graph of average free flow speed against each of the road geometry, that is, road width, number of lanes, shoulder width, number of intersections, travel way width and number of traffic control units are shown in Figures 6-10. These outcomes can form the basis of adjustment factors for the free flow speed of traffic stream on an urban arterial. For instance, a road width of $8 \mathrm{~m}$ or more will not attract any reduction in operating value but lower widths will attract at a unit rate of $17 \mathrm{~km} / \mathrm{hr}$ or less. The corresponding values for the different factors are summarized in Table 8.

Table 5: Mean Free Flow Speed Statistics (mean + standard deviation) (km/hr)

\begin{tabular}{|l|c|c|c|c|}
\hline Section & A & B & C & D \\
\hline Wet condition & $73.8 \pm 11.10$ & $66.8 \pm 14.99$ & $71.1 \pm 10.72$ & $57.5 \pm 6.10$ \\
Dry condition & $72.0 \pm 12.00$ & $80.8 \pm 7.18$ & $74.2 \pm 5.00$ & $58.0 \pm 7.76$ \\
Reduction (km/hr) & 1.8 & 14.0 & 3.1 & 0.5 \\
\% Reduction & 2.2 & 21.0 & 4.2 & 0.87 \\
\hline
\end{tabular}

Table 6: True Free Flow Speed/pavement Condition Relationship

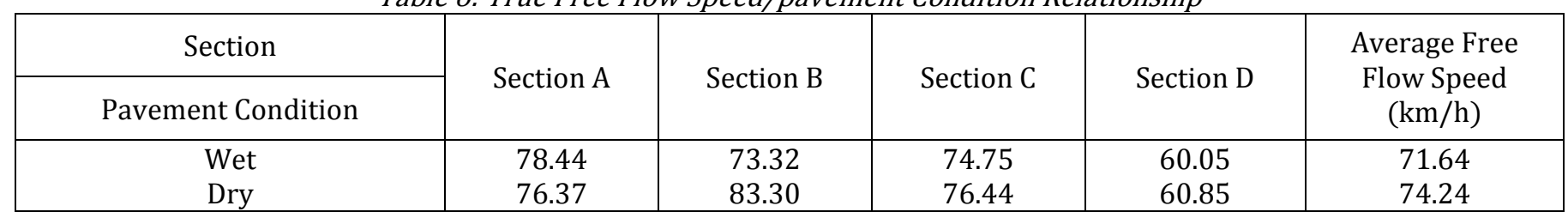

Percentage reduction in free flow speed on wet pavement $=\frac{100(74.24-71.64)}{74.24}=3.5 \%$

Table 7:Summary of Free Flow Speed - Road Geometry Relationship

\begin{tabular}{|c|c|c|c|c|c|c|}
\hline Section & $\begin{array}{c}\text { Road } \\
\text { width } \\
(\mathrm{m})\end{array}$ & $\begin{array}{c}\text { Shoulder } \\
\text { with }(\mathrm{m})\end{array}$ & $\begin{array}{c}\text { Number of } \\
\text { lanes }\end{array}$ & $\begin{array}{c}\text { Number of } \\
\text { intersection }\end{array}$ & $\begin{array}{c}\text { Number of } \\
\text { traffic control } \\
\text { unit }\end{array}$ & $\begin{array}{c}\text { Mean free flow speed } \\
(\mathrm{km} / \mathrm{h})\end{array}$ \\
\hline A & 8.10 & 2.3 & 2 & 11 & 1 & 75.31 \\
B & 10.7 & 3.0 & 3 & 9 & - & 75.5 \\
C & 10.7 & 2.7 & 3 & 5 & 1 & 73.7 \\
D & 7.1 & 2.2 & 1 & 15 & 1 & 59.0 \\
\hline
\end{tabular}

Table 8: Quantitative Measure of Geometric Effect on Free Flow Speed

\begin{tabular}{|l|l|c|c|c|}
\hline S/No. & \multicolumn{1}{|c|}{ Factor } & Unit & Critical value & Rate of reduction (km/hr/unit) \\
\hline 1 & Road width & $\mathrm{m}$ & 8 & 17.0 \\
2 & No. of Lanes & No. & 2 & 15.0 \\
3 & Shoulder width & $\mathrm{m}$ & 1.2 & 0.5 \\
4 & No. of intersections & $\mathrm{mo}$ & 4 & 0.5 \\
5 & Overall roadway & No. & 20 & 17.0 \\
6 & No. of control units & 1 & - \\
\hline
\end{tabular}




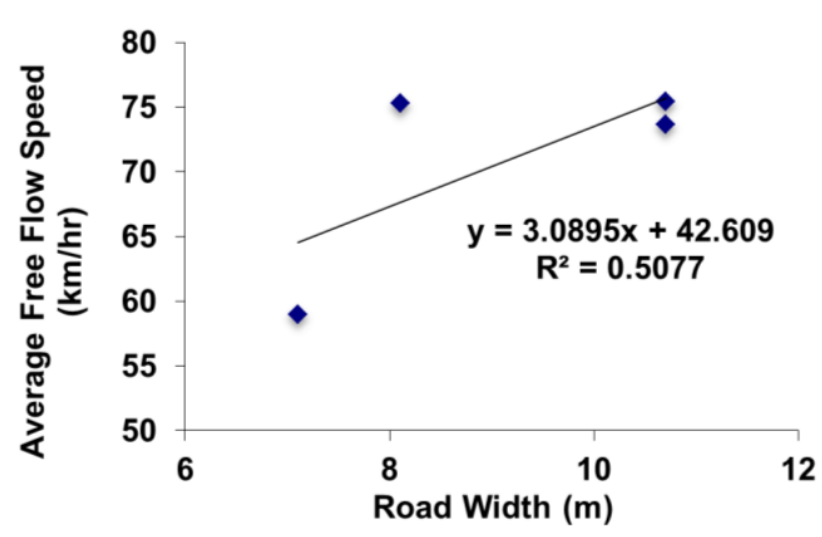

Figure 6: Average free flow speed against road width

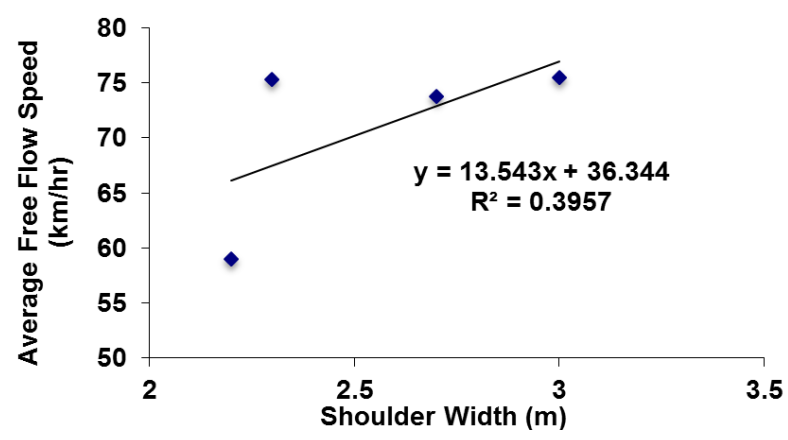

Figure 8: Average free flow speed against shoulder width

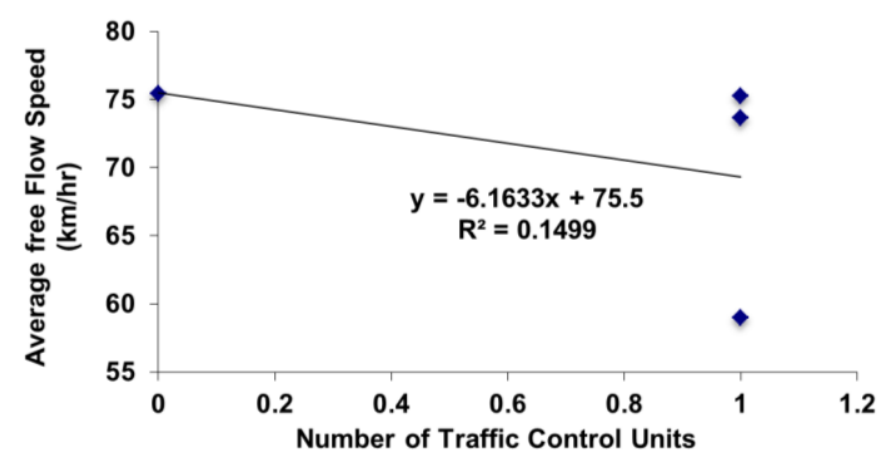

Figure 10: Average free flow speed against number of traffic control units

\section{DISCUSSIONS}

Figures 2-5, respectively show that the average free flow speed decreases with increase in drivers' age, number of passengers in a car, car age and number of parked cars along the arterial, with corresponding slopes computed as -0.46, -0.548, -1.59 and -1.004. The negative signs further indicating reduction of free flow speeds as these four factors increase.

Results of Table 6 show that wet pavement also reduce the free low speed by as much as $10-14 \mathrm{~km} / \mathrm{hr}$ or $12-21 \%$, which are relatively higher than $10 \mathrm{~km} / \mathrm{hr}$ and $8 \%$ reported for rains and wet pavement and other countries, respectively [16]. This may be due to the general state of pavement conditions, driver's age and state of mind, roadside land-use and density,

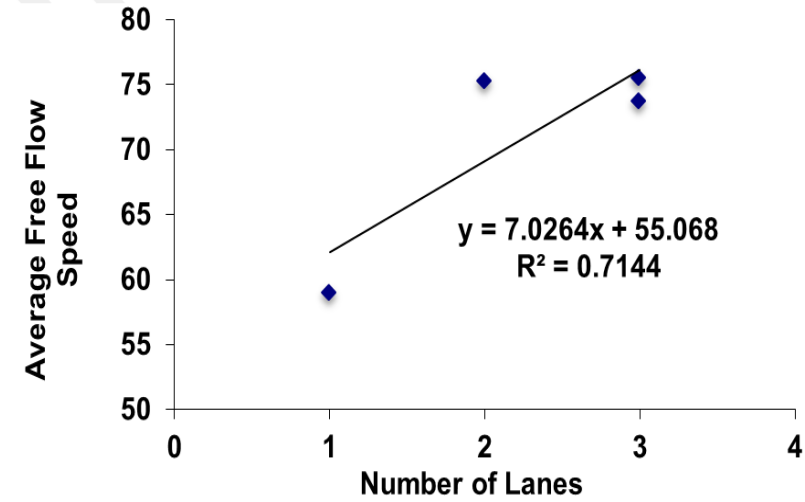

Figure 7: Average free flow speed against number of lanes

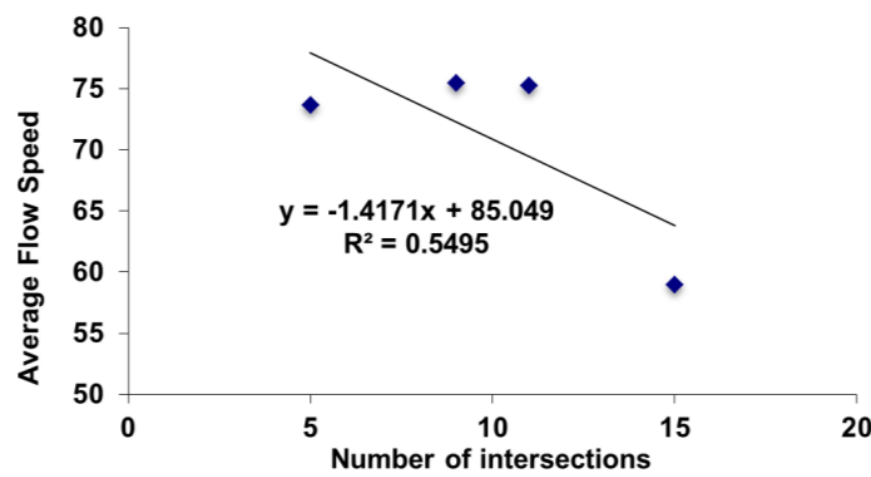

Figure 9: Average free flow speed against number of intersections

businesses and parking. The variation in free flow speed of $66.8,71.1$ and $57.5 \mathrm{~km} / \mathrm{hr}$ during wet conditions and respective $80.8,74.2$ and $58.0 \mathrm{~km} / \mathrm{hr}$ for dry pavement, shown in Table 5(with corresponding coefficient of variation of 22.4, 15.1 and $10.6 \%$ for wet and $8.9,6.7$ and $13.9 \%$, for dry conditions)for all the sections, except section A attest to this deduction. Better performances of the drivers during dry weather clearly show the influence. However, the results for section A, being the only undivided portion allows the drivers more latitude to demonstrate their personal attribute and desire at overtaking and performing other movement maneuvers, showed otherwise.

Average free flow speed increases with increase in road width, number of lanes and shoulder width [17] as shown in Figures 6, 7 and 8 with slopes of 3.089, 7.026 and 13.54, respectively. Figures 9 and 10 with slopes of -1.417 and -6.163 , respectively, however show a decrease of free flow speed with increase in number of intersections and traffic control units.

\section{CONCLUSIONS}

The following conclusions were reached from the study. 
1. The traffic volume distribution on an urban arterial in Ilorin is trimodal with morning, afternoon and evening peaks and lulls in between.

2. The changes in the road geometry on each section of the arterial in terms of shoulder width, number of lanes, road/carriageway width and distance of nearest obstruction to the edge of the road do affect the instantaneous speeds. The corresponding numerical values of the instantaneous speeds for Offa Garage-Emir's Road are about 10.5, 15, 27 and $17 \mathrm{~km} / \mathrm{hr}$ for sections $\mathrm{A}, \mathrm{B}, \mathrm{C}$ and $\mathrm{D}$ respectively.

3. Different free flow speeds operate on distinct sections of the arterial. The values are 72.0, 80.8, 74.2 and $58.0 \mathrm{~km} / \mathrm{hr}$ for section A, B, C and D, respectively for dry condition, while the corresponding values for wet conditions are 73.9, $66.8,71.1$ and $57.5 \mathrm{~km} / \mathrm{hr}$.Section B has the highest average free flow speed while, Section $D$ has the lowest average free flow speed. The density or level of usage reflects the decrease in free low speed values along the route.

4. A strong linear relationship exists between free flow speed of commuter vehicles and drivers' age, number of passengers in the car and car age at $\mathrm{R}^{2}$ values of over $85 \%$ with following respective rates of (a) decrease of $0.46 \mathrm{~km} / \mathrm{hr} / \mathrm{yr}$ of driver's age, (b) an increase of $0.53 \mathrm{~km} / \mathrm{hr}$ per passenger in the car, (c) a decrease of $1.48 \mathrm{~km} / \mathrm{hr} / \mathrm{yr}$ of age of car.

5. However there is no relationship between free flow speed and road side parking, road width, shoulder width, number of intersections, travel way and number of travel control units, with $\mathrm{R}^{2}$ values of $14.9-55 \%$, situations due to other prevailing factors.

6. The average free flow speed of commercial saloon cars is lower on wet pavement than on dry pavement, the percentage reduction being about $12 \%$.

\section{ACKNOWLEDGEMENTS}

The Author is grateful to the various Research workers and authors for their information, excellent books and Journals, which were consulted, during this study.

\section{REFERENCES}

[1] Agent, K. R., Evaluation of 70 MPH Speed Limits in Kentucky, Kentucky Transportation Centre, Report No. KTC-08-10, College of Engineering, University of Kentucky, Lexington, KY, 2008, 40506-0281
[2] Dixson, K. K., Wu, C.H, Sarasua, W. and Daniel, J. "Posted and Free-Flow Speeds for Rural Multilane Highways in Georgia", ASCE Journal of Transportation Engineering, Vol. 125, Number 6, pp 54-61, 1999.

[3] Kyte. M., Khatib, Z., Shannon, P. and Kitchener, F. "Effect of Environmental Factors on Free-Flow Speed", Transportation Research Circular E-C018: 4th International Symposium on Highway Capacity, 2000, pp 34-42.

[4] Semeidu, A. M. Impact of Highway Geometry and Posted Speed on Operating Speed at Multi-Lane Highways in Egypt. Journal of Advanced Research , Vol. 4 Number 6, 2012. pp. 515-523, 2012

[5] Modi, V., Kondyli, A., Washburn, S. and McLeod, D. "Freeway Capacity Estimation Method for Planning Applications", Journal of Transportation Engineering, Vol. 140, Number 9, 2014.

[6] Blake, L.S. Civil Engineering Reference Book, $4^{\text {th }}$ edition, Butter Work and Co. Publishers Ltd. New York , pp 25-26, 1989.

[7] Highway Capacity Manual (HCM) Transportation Research Board, National Research Council, Washington D.C., 2010

[8] Rao, A.M. and Rao, K.R. (2014). Free Speed Modeling for Urban Arterials - A Case Study of Delhi. Periodica Polytechnica Transportation Engineering. 43(3). pp. 111-119. 2015.

[9] Transportation Research Board,. Modeling Operating Speed. Transportation Research Circular Number EC 151, 2011.

[10] Luca, M. D., Lamberi, R. and Dell' Acqua, G. Freeway Flow Speed: A case study in Italy. Procedia-Social and Behavioral Sciences. 54(4) pp.628-636, 2012.

[11] Mingjun, L., Keping, L., Xiaohui, D. and Kaiying, W.. Implementation and Validity of Free Flow Speed Model of a Freeway. International Conference on Transportation Engineering. pp. 3452-3457. 2007.

[12] Liang, W. L., Kyte, F., Kitchener, F. and Shannon, P. Effect of Environmental Factors on Driver speed", Transportation Research record 1635, Transportation Research Board. Washington, D.C., 1998

[13] Longstreth, L. E., El-Zahhar, N., and Alcorn, M. B.. Exceptions to Hick's law: Explorations with a response duration measure. Journal of Experimental Psychology: General, 114, 417-434, 1985.

[14] Baird, K. M., Hoffmann, E. R., and Drury, C. G.. The effects of probe length on Fitts' law. Applied Ergonomics, 33, 9-14, 2002.

[15] Adeleke, 0. 0.. Analysis of Water Distribution Pipe Failure in Ilorin, Nigeria. Nigerian Journal of 
Technological Development. 3(1 and 2). pp. 45-53, 2003.

[16] Frazio, J., Wiedner, B. N. and Dearodoff, M. D. Estimation of Free Flow Speed. KSCE Journal of Civil Engineering, 18(2). pp. 646-650, 2014.
[17] Saifizul, A. A., Yamanaka, H. and Karim, M. R. Empirical Analysis of Gross Weight and Free Flow Speed and Consideration on its Relation with Differential Speed Limit. Accident Analysis \& Prevention 43(3), May 2011, pp. 1068-1073

\section{APPENDIX}

Table A1: Free Flow Speed Data in Respect of Various Factors for Section A

\begin{tabular}{|c|c|c|c|c|c|c|c|c|}
\hline S/NO & $\begin{array}{l}\text { Speed } 1 \\
(\mathrm{Km} / \mathrm{h})\end{array}$ & $\begin{array}{l}\text { Speed } 2 \\
(\mathrm{Km} / \mathrm{h})\end{array}$ & $\begin{array}{l}\text { Speed } 3 \\
(\mathrm{Km} / \mathrm{h})\end{array}$ & $\begin{array}{c}\text { Average Speed } \\
(\mathrm{km} / \mathrm{h})\end{array}$ & DA & NPIC & CA & NPC \\
\hline 1 & 75 & 80 & 90 & 81.6 & 29 & 4 & 1 & 15 \\
\hline$\frac{1}{2}$ & 65 & 70 & 55 & 63.3 & 35 & 2 & 3 & 18 \\
\hline $\begin{array}{l}2 \\
3\end{array}$ & 85 & 65 & 70 & 73.3 & 43 & 4 & 1 & 10 \\
\hline 3 & 80 & 80 & 85 & 82.6 & 47 & 6 & 2 & 14 \\
\hline $\begin{array}{l}4 \\
5\end{array}$ & 70 & 85 & 65 & 73.3 & 35 & 3 & 1 & 22 \\
\hline 5 & 75 & 70 & 80 & 75.0 & 40 & 2 & 2 & 16 \\
\hline $\begin{array}{l}6 \\
7\end{array}$ & 60 & 60 & 80 & 66.7 & 32 & 2 & 2 & 19 \\
\hline $\begin{array}{l}7 \\
0\end{array}$ & 70 & 65 & 80 & 71.6 & 28 & 3 & 1 & 21 \\
\hline $\begin{array}{l}8 \\
9\end{array}$ & 80 & 70 & 85 & 78.3 & 30 & 2 & 1 & 17 \\
\hline 9 & 70 & 85 & 65 & 73.3 & 29 & 2 & 3 & 24 \\
\hline 10 & 85 & 70 & 75 & 76.7 & 24 & 4 & 4 & 12 \\
\hline 11 & 90 & 60 & 90 & 80.0 & 39 & 2 & 2 & 30 \\
\hline $\begin{array}{l}12 \\
13\end{array}$ & 70 & 60 & 50 & 60.0 & 43 & 6 & 1 & 18 \\
\hline 13 & 65 & 65 & 70 & 66.7 & 45 & 4 & 4 & 15 \\
\hline $\begin{array}{l}14 \\
15\end{array}$ & 40 & 50 & 50 & 46.7 & 58 & 6 & 9 & 26 \\
\hline $\begin{array}{l}15 \\
16\end{array}$ & 55 & 70 & 85 & 70.0 & 42 & 2 & 1 & 14 \\
\hline $\begin{array}{l}16 \\
17\end{array}$ & 80 & 75 & 50 & 68.3 & 48 & 5 & 2 & 16 \\
\hline $\begin{array}{l}17 \\
18\end{array}$ & 65 & 50 & 40 & 51.7 & 32 & 5 & 5 & 20 \\
\hline 18 & 75 & 80 & 70 & 75.0 & 28 & 4 & 1 & 29 \\
\hline $\begin{array}{l}19 \\
20\end{array}$ & 90 & 90 & 95 & 91.7 & 31 & 3 & 1 & 18 \\
\hline 20 & 100 & 80 & 80 & 86.7 & 26 & 3 & 2 & 15 \\
\hline 21 & 80 & 55 & 40 & 58.3 & 43 & 4 & 4 & 25 \\
\hline $\begin{array}{l}22 \\
23\end{array}$ & 95 & 100 & 90 & 95.0 & 47 & 2 & 3 & 32 \\
\hline 23 & 75 & 75 & 80 & 76.7 & 38 & 3 & 6 & 16 \\
\hline 24 & 55 & 45 & 50 & 50.0 & 54 & 4 & 5 & 37 \\
\hline 25 & 70 & 55 & 60 & 61.7 & 62 & 3 & 9 & 29 \\
\hline 26 & 80 & 80 & 85 & 81.7 & 41 & 3 & 6 & 16 \\
\hline $\begin{array}{l}27 \\
28\end{array}$ & 90 & 70 & 65 & 75.0 & 40 & 2 & 4 & 19 \\
\hline $\begin{array}{l}28 \\
20\end{array}$ & 60 & 70 & 70 & 66.7 & 60 & 5 & 2 & 17 \\
\hline 29 & 70 & 75 & 90 & 78.3 & 28 & 3 & 3 & 20 \\
\hline 30 & 65 & 70 & 75 & 70.0 & 33 & 3 & 3 & 15 \\
\hline 31 & 75 & 65 & 65 & 68.3 & 37 & 4 & 4 & 17 \\
\hline $\begin{array}{l}32 \\
32\end{array}$ & 80 & 85 & 80 & 81.6 & 29 & 6 & 3 & 13 \\
\hline $\begin{array}{l}33 \\
34\end{array}$ & 85 & 85 & 100 & 90.0 & 36 & 2 & 2 & 12 \\
\hline 34 & 90 & 70 & 60 & 73.3 & 24 & 3 & 3 & 17 \\
\hline $\begin{array}{l}35 \\
36\end{array}$ & 65 & 85 & 90 & 80.0 & 28 & 2 & 4 & 25 \\
\hline 36 & 60 & 50 & 70 & 60.0 & 34 & 3 & 3 & 17 \\
\hline $\begin{array}{l}37 \\
38\end{array}$ & 45 & 60 & 55 & 53.3 & 48 & 3 & 7 & 19 \\
\hline 38 & 55 & 70 & 60 & 61.7 & 53 & 4 & 4 & 21 \\
\hline $\begin{array}{l}39 \\
40\end{array}$ & 80 & 90 & 90 & 86.7 & 42 & 6 & 2 & 20 \\
\hline
\end{tabular}

$D A=$ Driver's Age, $N I P C=$ No. of Passengers in Cars, $C A=$ Car Age, $N P C=$ No. of Parked Cars 